\title{
A Magyar Orvosok és Természetvizsgálók keszthelyi vándorgyưlése (1922)
}

\author{
Vértes László dr.
}

A magyar orvostörténelem kiemelkedő eseményei voltak a vándorgyúlések. Az első 1841-ben Pesten, az utolsó, a 41., 1933-ban Budapesten zajlott. Sajnos a folytatás mindmáig elmaradt.

1922-ben Keszthely (Zala megye) volt a 38. vándorgyưlés helyszíne. (A Balaton körül csak ott zajlott rendezvény.) Beck Mibály [1] jegyzi meg: „A háborút követően összesen négy vándorgyúlést tartottak: 1922-ben Keszthelyen, 1927-ben Pécsett, 1929-ben Sopronban és 1933-ban Budapesten. Az utolsó négy vándorgyúlés közül csak a budapestiról adták ki a korábban szokásos Munkálatokat.”

Gyermekkorom óta a Balaton és Keszthely rajongója vagyok. Keszthelyen kutattam a helyi vándorgyúlés esetleges anyagait.

\section{Napi Hírek}

1922. június 9.

„A Magyar Orvosok és Természetvizsgálók Vándorgyüléseinek állandó központi választmánya legutóbbi ülésén elhatározta, hogy újból feleleveníti a világháború tartama alatt szünetelt vándorgyúléseket, melyek a magyar orvosok és természetvizsgálók színe-javának már háromnegyed századnál hosszabb idő óta nemcsak találkozói, hanem értékes tudományos buvárlatainak közlői és terjesztői is voltak. Keszthely város szíves meghívása folytán a vándorgyúlés ez évben szeptember 3-6-ig terjedő időben Keszthelyen fogja üléseit tartani. Az előadások zöme a Röntgen-sugarak természetére és orvosi hasznára, az öröklés titokzatos jelenségeire, a belső elválasztású mirigyek élettani szerepére, a szerológia vívmányaira, a gyermekvédelemre és a gyermekhalandóság elleni küzdelemre fog vonatkozni. A vándorgyúlés tartama alatt délutánonkint kirándulások lesznek a környéknek orvosi és természettudományi szempontból nevezetesebb helyeire. A keszthelyi vándorgyúlés budapesti rendezőbizottságának elnöke Tóth Lajos dr. helyettes államtitkár, titkára Gorka Sándor dr. egyetemi helyettes tanár, tagjai Dollinger Gyula dr. egyetemi nyilvános rendes orvostanár mint az orvosi szakosztály elnöke és Ilosvay Lajos dr. nyugalmazott államtitkár mint a természettudományi szakosztály elnöke.”

\section{Zalai Közlöny}

1922. szeptember 5. 1. oldal

„Orvosok keszthelyi gyúlése

Keszthely, szept. 4. A magyar orvosok és természettudósok vasárnap délelőtt tartották meg vándorgyúlésüket, amelyeken a közoktatásügyi minisztert Tóth Lajos államtitkár képviselte. Kolbenschlag Béla főispán üdvözlő beszédet mondott. Azután következtek a tudományos előadások. Este vacsora volt. Ma délelőtt a röntgensugarak alkalmazásáról tartottak több értékes előadást.”

\section{Zalai Közlöny}

1922. szeptember 7. 2. oldal

„- A keszthelyi vándorgyúlés. A keszthelyi orvosi vándorgyúlés tagjai ma délután a hercegi parkon keresztül sétálva, kocsikon és autókon Hévízre rándultak ki. A fürdőtelep megtekintése után Reuchl Imre, Keszthely város bírája és a hévízi fürdőtelep bérlője látta vendégül a társaságot. A gyógyteremben tartott nagy banketten egymást érték a pohárköszöntők. Dollinger tanár annak a reményének adott kifejezést, hogy amint a hévízi forrás egészségessé teszi a bénákat, meg fogjuk találni azt a forrást is, mely talpraállíthatja újra szegény csonka hazánkat. Ez a forrás az emberek mentalitásában rejlik.”

\section{A Magyar Orvosok és Természetvizsgálók keszthelyi vándorgyúlése (1922) a korabeli tudományos folyóiratokban}

\section{Orvosi Hetilap}

1922. (szeptember 17.) 38. szám, 374. oldal

„Vegyes hírek. A magyar orvosok és természetvizsgálók 38. vándorgyúlése szeptember 3-6-áig folyt le Keszthelyen a legteljesebb sikerrel. Az utolsó vándorgyúlésnek 1914-ben kellett volna megtartatnia Nagyszebenben, de a közbejött háború miatt elmaradt; azóta szünetelt ez az intézmény, melynek nemcsak az a feladata, hogy a tudománnyal foglalkozók személyes érintkezése, eszmecseré- 
je, előadások és bemutatások révén a tudományt elömozdítsa, hanem az is, hogy felváltva az ország különböző vidékein érdeklődést keltsen tágasabb körben az orvosi és természettudomány iránt s másfelől megismertesse hazánk különböző vidékeit a vándorgyúlésen résztvevőkkel. A vándorgyưlések vezetősége elérkezettnek látta most az időt a gyúlések felújítására s hogy számítása helyes volt, azt a gyuulés szép sikere tanúsítja. Úgy az együttes üléseken tartott előadások, mint a szakosztályokban előadottak magas színvonalon állottak s az előadóknak szép számú, figyelmes és hálás közönségük volt a gyưlés utolsó napjáig. Köszönettel tartozunk a vándor- gyưlés vezetőségének, hogy lehetővé tette a magyar orvos-természettudományi kultúrának ezt az ünnepét $s$ köszönettel tartozunk a kedves balatonmenti városnak azért a vendégszeretetért, amellyel a négyszáznál nagyobb számú összesereglett tudósokat és a tudomány iránt érdeklődőket fogadta.

P.S. Az Orvosi Hetilap örök ellenlábasa, a Gyógyászat kicsit »bőbeszédúbb« volt. Már az augusztus 22-én megjelent 35. száma közölte »A Magyar Orvosok és Természetvizsgálók XXXVIII. keszthelyi vándorgyúlésének előrajza « c. írást, a gyưlés részletes programjával. A 38. szám (szept. 17-én) részletes beszámolót közölt - szer-

\section{Eqyesületek és Testületek.}

A Magyar Orvosok és Természetvizsgálók XXXVIII. keszthelyi vándorgyülése.

'A közbejött háboru és forradalmak miath, 1912 óta szünelelt a magyar orrosok és természetyizsgálók népszerü rándorgyülése, mig most a követliczó programmial log lefolyni:

- ig22. szember 2-án; szombaton, este 9 órakor ismerliedési est éś társastacsora a Hungária nagytermében. 1922. szeptember 3-án, vasárnap: Regóel 8-10 óráig körséta a városban. Délelött fél f1 órakor ümnepélyes megnvitó közgyülés az Urảniában. Tárgyai: 1. Elnöki meglnyitó. 2. Titkári jèlentés 3. Elnöki elóterjesztésel. 4. Dr. Chyzer Kornél-előadás: A nagy tömeg'ek élelzer Kornél-elöadás: A nagy tomegek elelmezéséröl. Tartja: Dr. Ilosvay Lajos, nyug. államtițár. 5. Bene-Bugát-elöadás: Gycrben. Tartja: dr. Heim Pál, az Exzsébet Tud.Egyetem reklora. Délután ¿ órakor gözhajókirándulás. Badacsonyba. Visszaérlsezés után este 8 órakor Helikonı esì a balátonparti sétányon, 9 órakor társasvacsora a balatonparti Hullám-ban. 1922. szeptember 4-éǹ, hétfön: Regsej 9 orakor a XIV. században épült plébániai templom megtelintése. Délelőtt 10-1/21 óráig együttes ülés az Urániában. Fö théma: A radioaktivitás jelenségel természettudományi és orrosi szempontból. Előadók: dr. Groh Gyula, állatoriosı fóiskolar tanár: Az atómok szcrkezete és átalakulása. Dr. Rhorer László, áliatoriosi fóiskolai és egyetemi tanár: A Röntgen-sugarakra vonatkozó ujabb vizsgálatok. Dr. Kelen Béla, az egyetemi Röntgen-intézet igazgatója: Béla, az egyetemi Rontgen-intézet orvos allalmazása. Az A Röadásokat hozzászólások kövelil. Délután elöadásokat hozzászólások kövelik. Délután s a tözcoüizem mes'tekintése. Este 7 óralion. Bogdánlf́y Odön, ny, h. államtilkár "A permetezó öntözés" cimen tart velitett képelikel és mozgóképpel illuisztrált elöndäst 1922

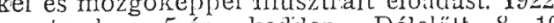
széptember 5-én, a gazdasági alsadémia és a Balalonı Muzeum megteluintése. Délelótt $10-12$ óráig együittes ülés az Urániában. Fó théma: Az örölicéstan haladása és jelentősẻge. Elöadók Dr. Gorka Sándlor, egyetemz h. tanár: A orokléstan alapclvei és az öröklés szabá ilyai. (Mendel-,' Bateson-, Morgan- éś BridgesTéle szabály.) Grabner 'Emil, à m. kir. növénynemesitó intézet igazgatója: Az örökléstan jèlentösége a növénynemesitésłien és a többtermelésben. "Az eTónlásolrat hozzászóla sok kōvetik. Déli 12-1/2 óráig szakoszlály elöadásol. Délután $1 / 23$ 'órakor kiránduilás Hévizgyógyfürdóbe. 1922. szeptember 6-án, szerdán: Reggel 8-10 óráig a városi közkórház megtelkintése. Délelött $10-12$ oráig együttes ülés. Fớ théma: A belső, elválasztás jelenségei Elöadók: Dr. Farkas Géza eg' ny. r. tanár: A belä cliólasalás élettan. Dy. bácó Koránj Sánclor, egyetemi ny.

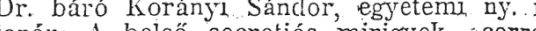
tanál: A belsô secretiós mirigyek corro latiói. Az előadásokat hozzászólások (dr. Paal Ârpád, egyet. m. tanár: A nörények ibelsö. elválasztása stb.) követik. Déli 12-z óráig szakosztályı ülések. Délután 4 órakior ùnnepélres zároülés. Tároyi. I Elnöki meghitó

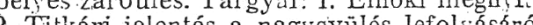
. Titkar jelentés a nagygyülés lefolyásáról. 3. Kovács József́-elóadás: Az emberi test aلlkotásának törvényszerüségei. Tartja: Dr. Lenhossék Mihály, egyetemi ny. r. tanár. 4. Elnölij bezáró. Este 7 óralior dr. Lovassy tart a Balaton vidékén éló raqajoź́midnrikról a Baláct. A bejelentett és még bejelen(ejelentendó szalkoszlályi elóalások és elöterjesztések jegyzéke és ideje később lesz nyilwánosságra hozva. A népszerü tudományos elōadásokon, valamint a megnyitó és bezáró ülésen, ugyszintén a szakosztályok ülésein a nagykōzönséget is szivesen látják.

A vándorgyülésre vonatliozó tudnuvalỏk a köretkezóls:

1. A vándorgyülés tagja lehet mindenlii, ki az orvos-, természet-és tås sadalomtudomanyokat müveli vagy kedveli, ha a 200 koronában megállapitolt tag'dijat lefizeti.

A tagok megliapják a iMunlíalatokat: s egyéb kiosztásra kerülö nyomtatványoliat s $a z$ elszállásolás (esetlég a mérsélielt ăru' utazás) és a kirándulások kedvezményẻben részesülnel

Előadást csak a gyūlésre beirt tagok tarthatnak. Az elöadás tartama legfeljebb 10 perc és csak az clnök engedélyếvel tarthat hosszabb ideig.

A nagogülés azon tagjâi, hỉk elöadåst tartanı szándéloznak, de annak cimét 'idáig még nem jelenteltél be, azt mennél elöbb jelentsék be. Az orvosı elöadások dr. Dollinger Gyula egłretemi ny. r. tanár, szakosztályr ügyvezelö elnökneli Budapest, VII. ker. Rákóczi-ut 52, sz. a természcttudománvi és társadalomtudományı elüadísok dr. Gorka Sándor egyetemi h. tanár, szakosztályi tỉikärSándor egyetemi h. tinnár, szakosztályi tíkar-
nak (Budapest, VIII., Eszterházy-utea 16. sz.) jelentendók be. 
A gyülćsck jegyzőlionyreinel gyors és pontos szerkěszthetése érdekében az elöádók elöadásnik rövid kivonatát az ülésre misukkal hoznı s elöadḱs után a jegyzöncli átadn sziveskedjenek.

2. A' rándorgyülésre érkező tılgok szi eskedjenek megérkezésük után a vándorgyülési irodába (gazdasági akadémia) fáradni, ahol minden szülsségeses iránt tájéliozódást szcrezhetnek:

3. A tagdijat, melynek befizetése után kellő elszállásolásról törtẻnik gondosliodảs, a vándorgyülés pénztárnoliának (Csili Ernó nemzetı muzeum osztályigazgató, Budapest, VIII., Nemzeti Nuzeum, Alllattér legkésóbb augusztus hó 30-áig' kell beküldeni, ezen t'ul már csak a helyszinén, Keszthelyen lehet béiratkoznı, személyesen vagy megłbizás utján. A tagsági jegynek idején való līivállása tehát a gyülés tag'jainak érdekében van, hogy az elszállásolásról és egvéb kedvezménvek meg'szerzéséröl idejekorán intézkędés törtenhessék.

zője ismeretlen - a gyúlésről »A magyar orvosok és természetvizsgálók XXXVIII. vándorgyúlése Keszthelyen, 1922. szept. 3-6.« címmel (535-536. о.).”

\section{Állattani Közlemények}

\section{2. október 31. 1-4 füzet, 82. oldal}

„A magyar orvosok és természetvizsgálók f. é. szeptemberben tartották meg 38-adik vándorgyúlésüket Keszthelyen. Az előadott tárgyak közt zoologiai érdekúek is voltak. Dr. Nagy Jenő a délmagyarországi gémtelepekről szólt. Dr. Gorka Sándornak az öröklés haladásáról szóló előadása mindazokat a törvényszerúségeket ismertette, amelyek a Mendel-féle örökléstörvény alól kitérnek. Dr. Lovassy Sándor a vidék ragadozó madarainak életét jellemezte. Dr. Lenhossék Mihály az emberi-test alkotásának törvényszerúségeirôl értekezett. Dr. Zimmermann Ágoston a mellékpaizsmirigyek anatomiájáról és a megmaradó csecsemőmirigyről beszélt, Dr. Tamássy Béla orvos pedig a légyveszedelem elleni intézkedéseket sürgette.”
4 Minden iránt, ami a vándorgyülésre vomatkozik, a központi válaszlmány tilkáránál: dr. Gorka Sảndornál (Budapest, VIII., Eszterházy-utca 16. sz.), to rábbá a helyı bizot:ság elnökséoénél: dr. Lovassy Sándor, gazdasági fötanácsosnál Keszthelyen tudakozódhatni.

Figyelmeztetés! Tanácsos iđlejekorãn beiratkozni, mert csak igr lehet a lakásoliat jó elöre biztositani s a tagok az erról szóló értesitést is idejében megkaphatjálí. Szrveskédjenek arról is értesiteni, hogy szállóban, vagì macánhelven esetlèg intézetben óhajtanak lakni. Utóbbi két helyen (esetieg a szállóban is)j a lakás ingyenes.

Reméljük, hogy a magyar gyóǵyszerészi kar mint a multban, ezuttal is szép számban fog a vándorgyïlésen résztrenu s talán lehetségies lesz a Külön gyógyszerészelı szaliosztály megalakitása.

\section{Gyógyszerészi Hetilap}

\section{390-391. oldal}

„A Magyar Orvosok és Természetvizsgálók XXXVIII. keszthelyi vándorgyưlése" címmel szerkesztőségi közleményt adott ki. Érdemi áttekintés nevekkel, adatokkal. A kor kiváló egyetemi tanárai tartottak előadást.

\section{Köszönetnyilvánítás}

E helyen is köszönet illeti Kocsondiné Eisenkorb Györgyi olvasószolgálatos és tájékoztató könyvtáros (Keszthely) és Nyiri Krisztina (Budapest) értékes, sokoldalú segítségét.

\section{Irodalom}

[1] Beck M. Commemorative and award medals issued by the Itinerary Congresses of the Hungarian Physicians and Natural Scientists. [A Magyar Orvosok és Természetvizsgálók Vándorgyúléseinek emlékérmei és jutalomérmei.] Orvostörténeti Közlemények 1987; 117-120: 309.

\section{A rendezvények és kongresszusok híranyagának leadása}

a lap megjelenése előtt legalább 40 nappal lehetséges, a 6 hetes nyomdai átfutás miatt. Kérjük megrendelőink szíves megértését.

A híranyagokat a következő címre kérjük:

Orvosi Hetilap titkársága: edit.budai@akademiai.hu

Akadémiai Kiadó Zrt. 